\title{
THE ACTIVATION OF THE INTERNATIONAL CRIMINAL COURT'S JURISDiCTION OVER THE CRIME OF AGGRESSION: \\ INTERNATIONAL INSTITUTIONAL LAW AND DISPUTE SETTLEMENT PERSPECTIVES
}

\author{
Meagan S. Wong ${ }^{\bullet}$
}

\section{Keywords:}

Crime of aggression; International Criminal Court; Subsequent agreement and subsequent practice under Article 31(3); Vienna Convention on the Law of Treaties; International Law Commission; Rules of the International Organization; International institutional law; Dispute settlement

\begin{abstract}
In 2017 the plenary organ of the ICC, the ASP, adopted Resolution ICC-ASP/16/Res.5, activating the Court's jurisdiction over the crime of aggression; and confirming an interpretation of the Rome Statute. While the characterization of this Resolution as either a subsequent agreement or subsequent practice under Article 31(3) VCLT is relevant to treaty interpretation of the Rome Statute, this article submits that this Resolution is clearly a Rule of the International Organization, taken by one of its organs. Resolution ICC-ASP/16/Res.5 may constitute a 'relevant rule' of interpretation with regard to the Rome Statute, thereby taking precedence over the general rules of interpretation in Articles 31 and 32 of the VCLT; particularly when the interpreter is an organ of the ICC. If a dispute arises with regard to the interpretation of the Rome Statute on the crime of aggression, a specialist regime at the ICC exists for the settlement of disputes.
\end{abstract}

\section{Introduction}

On 14 December 2017, the Assembly of State Parties of the Rome Statute of the International Criminal Court (“ASP”) session in New York, adopted by consensus Resolution ICC-ASP/16. Res.5 on the 14 December 2017, titled 'Activation of the jurisdiction of the Court over the crime of aggression' (“New York Activation Decision”). Accordingly, in July 2018, the jurisdiction of the International Criminal Court ("ICC") over the crime of aggression was activated. ${ }^{1}$ Prior to the New York Activation Decision, the crime of aggression at the ICC remained dormant, which speaks to the significance of this decision by States Parties. ${ }^{2}$

\footnotetext{
- Lecturer in Law, University of Essex. The author wishes to express gratitude to Christiane Ahlborn, Roger Clark, Olufemi Elias, Niccolò Lanzoni, Noam Lubell and Martins Paparinskis for their comments on an earlier draft of this article.

${ }^{1}$ Paragraph 2: '[d]ecides to activate the Court's jurisdiction over the crime of aggression as of 17 July 2018.

2 The President of the Assembly of State Parties to the Rome Statute of the International Criminal Court, Christian Wenaweser, had reflected, ' $[\mathrm{g}]$ iven the high stakes and the late hour, I put a final proposal on the table, which today is the text of paragraph 3 of Articles 15 bis and 15 ter of the Rome Statute: the activation of both triggers is thus subject to a future decision of states parties, to be taken after 1 January 2017 by at least an absolute majority of two-thirds of states parties', see Christian Wenaweser, 'Reaching the Kampala Compromise on Aggression: The Chair's Perspective' (2010) 23 Leiden Journal of International Law 883, 887. See also Niels M Blokker and Stefan Barriga, 'Conditions for
} 
In anticipation of future cases on the crime of aggression that may arise at the ICC, two concomitant issues need to be addressed. First, the scope of the jurisdiction that the Court may exercise over the crime of aggression. In other words, who may be subject to the jurisdiction of the ICC for the crime of aggression. The answer lies in the interpretation of the provisions in the Rome Statute relevant to the crime of aggression. Yet, questions on interpretation may also be disputes with regard to the interpretation of the ICC's jurisdiction over this crime. ${ }^{3}$ As famously defined by the Permanent Court of International Justice ("PCIJ"), a dispute is 'a disagreement on a point of law or fact, a conflict of legal views or of interests between two persons. ${ }^{44}$ This leads to the second issue: the dispute settlement mechanisms available to States at the ICC as well as the international legal order in the event that a dispute may arise with regard to the Rome Statute on the crime of aggression.

In 1996, when States Parties adopted the Rome Statute on the International Criminal Court ("Rome Statute"), the crime of aggression was stipulated as a crime that the Court may exercise jurisdiction over, ${ }^{5}$ but remained undefined. Instead, (now) former Article 5(2) stipulated:

The Court shall exercise jurisdiction over the crime of aggression once a provision is adopted in accordance with articles 121 and 123 defining the crime and setting out the conditions under which the Court shall exercise jurisdiction with respect to this crime. Such a provision shall be consistent with the relevant provisions of the Charter of the United Nations. ${ }^{6}$

Already at the very early stages of preparatory works on the definition of the crime of aggression and the conditions of jurisdiction, there was ambiguity with regard to the amendment process. One of the key questions in the preparatory works was how amendments to the Statute were to enter into force. Notably Article 5(2) of the Rome Statute, stipulates that the intended 'provision' should be 'adopted in accordance' with Article 121, i.e. the provisions in the Rome Statute that govern amendments. However, Articles 5(2) and 121 do not appear prima facie compatible, as the language in the former provision refers to 'adoption' of the definition and conditions of exercise of jurisdiction over the crime, whilst Article 121 as read in its entirety suggests that any amendment 'adopted' will 'enter into force' pursuant to either Article 121(4) or

the Exercise of Jurisdiction Based on Security Council Referrals' in Claus Kress and Stefan Barriga (eds), Crime of Aggression Library: A Commentary, vol 1 (Cambridge University Press 2017) 653.

${ }^{3}$ Henry G Schermers and Niels M Blokker, International Institutional Law (6th edn, Brill: Nijhoff 2018) 871.

${ }^{4}$ Mavrommatis Palestine Concessions (Greece v UK) PCIJ Rep 1924, Series A, No.22 at 11.

${ }^{5}$ Article 5(1), Rome Statute.

${ }^{6}$ This paragraph was deleted was deleted in accordance with RC/Res.6, annex I, of 11 June 2010.

${ }^{7}$ Roger Clark, 'Ambiguities in Articles 5(2), 121 and 123 of the Rome Statute' (2009) 41 Case Western Reserve Journal of International Law 413. 
(5). As former Article 5(2) neglects to specify an entry into force procedure for the amendments to the Rome Statute on the crime of aggression, there was an ambiguity with respect to how Article 121 should be interpreted. In the earlier stages of negotiations, States had contemplated that a 'special entry-into-force mechanism' should be formulated 'to cut the Gordian Knot'.

The ambiguity prevailed throughout the negotiations leading to the Review Conference (Article 123 of the Rome Statute) in Kampala in 2010, as well as during the Conference itself. Thus, even though States Parties adopted Resolution RC/Res.6 by consensus, which comprised amendments to the Rome Statute on the crime of aggression ("Kampala Amendments"), how the amendments may enter into force remained a contentious issue between scholars and States alike. As will be discussed below, this question is premised on whether the amendments on the crime of aggression enter into force in accordance with the sui generis amendment process as adopted by States Parties in Kampala or with Article 121 of the Rome Statute that governs amendments. It may be wondered what the practical significance is for such a technical question of treaty law. The answer is that entry into force of the amendments pertains directly to the scope of jurisdiction that the Court may exercise over the crime of aggression as it determines who may be subject to the Court's jurisdiction.

The ICC's jurisdiction over the crime of aggression has been a frequent subject of scholarly debate in the seven years after the Review Conference in Kampala, whereby key negotiators and scholars wrote extensively on the interpretation of the Kampala Amendments. ${ }^{9}$ Two prevailing positions can be deduced: first, the ICC may exercise jurisdiction over the crime of aggression so long as either the intended aggressed State or alleged aggressor State has ratified the Kampala Amendments; ${ }^{10}$ and alternatively, the Court may not exercise jurisdiction over nationals of States Parties that have not ratified the Kampala Amendments - a submission that argues that both

\footnotetext{
${ }^{8}$ Claus Kress and Leonie von Holtzendorff, 'The Kampala Compromise on the Crime of Aggression' (2010) 8 Journal of International Criminal Justice 1179, 1199. See also Stefan Barriga, Wolfgang Danspeckgruber and Christian Wenaweser, The Princeton Process on the Crime of Aggression: Materials of the Special Working Group on the Crime of Aggression, 2003-2009 (Lynne Rienner Publishers 2010) 51; Astrid Reisinger Coracini, 'Amended Most Serious Crimes': A New Category of Core Crimes within the Jurisdiction but out of the Reach of the International Criminal Court?’ (2008) 21 Leiden Journal of International Law 699, 716. For a criticism, see Andreas Zimmermann, 'Amending the Amendment Provisions of the Rome Statute: The Kampala Compromise on the Crime of Aggression and the Law of Treaties' (2012) 10 Journal of International Criminal Justice 209, 227.

${ }^{9}$ Kress and von Holtzendorff (n 9); Stefan Barriga and Leena Grover, 'A Historic Breakthrough on the Crime of Aggression' (2011) 105 American Journal of International Law 517; Stefan Barriga and Niels Blokker, 'Entry into Force and Conditions for the Exercise of Jurisdiction: Cross-Cutting Issues' in Claus Kress and Stefan Barriga (eds), Crime of Aggression Library: A Commentary, vol 1 (Cambridge University Press 2017); Roger Clark, 'Exercise of Jurisdiction over the Crime of Aggression (International Criminal Court)' [2019] Max Planck Encyclopedia of International Procedural Law.

${ }^{10}$ Stefan Barriga and Niels Blokker, 'Conditions for the Exercise of Jurisdiction Based on State Referrals and Proprio Motu Investigations' in Stefan Barriga and Claus Kress (eds), Crime of Aggression Library: A Commentary, vol 1 (Cambridge University Press 2017) 668-672; Meagan Wong, 'Ratifying the Amendments to the Rome Statute of the International Criminal Court on the Crime of Aggression’ (2016) 19 Max Planck Yearbook of United Nations Law 176, 208; Kress and von Holtzendorff (n 9) 1212-1215.
} 
intended aggressed State and alleged aggressor State must ratify the Amendments. ${ }^{11}$ These scholarly positions were also reflective of the positions of States Parties, ${ }^{12}$ which culminated in general uncertainty with respect to how the amendments would enter into force, and the jurisdictional scope of ICC over the crime of aggression. The uncertainty extended to whether the ASP in New York would be able to resolve this outstanding issue with a view to activating the Court's jurisdiction over the crime of aggression. Yet, States Parties appeared to have taken a step further than anticipated, as the conflicting positions deliberated in New York culminated in an Operative paragraph in the Activation Decision:

Confirms in the case of a State referral or proprio motu investigation the Court shall not exercise its jurisdiction regarding a crime of aggression when committed by a national or on the territory of a State Party that has not ratified or accepted these amendments.

Despite adoption by consensus, this paragraph does not reflect the position of all States Parties present at the ASP at New York. Some States Parties had previously expressed their preference for a broader jurisdiction of the Court with regard to the crime of aggression. It may appear as if these States Parties have conceded on their original positions on the scope of the jurisdictional regime of the ICC over the crime of aggression in light of obtaining a consensus in order to activate the Court's jurisdiction over the crime. ${ }^{13}$

Yet, given the lack of clarity with regard to the entry into force of the Kampala amendments, it is significant that the ASP confirmed the scope of the jurisdiction of the crime of aggression in the New York Activation Decision. The New York Activation Decision serves as a means of treaty interpretation in this regard. According to the legal framework of the law of treaties, it is possible that the New York Activation Decision may be a subsequent agreement or subsequent practice according to Article 31(3) of the Vienna Convention on the Law of Treaties 1969 ("VCLT"). The recent work of the International Law Commission ("ILC") on its Conclusions on subsequent agreements and subsequent practice in relation to the interpretation of treaties ("ILC Conclusions") is particularly insightful in this regard. Yet, another important dimension is that the

\footnotetext{
${ }_{11}$ Dapo Akande and Antonios Tzanakopoulos, 'Treaty Law and ICC Jurisdiction over the Crime of Aggression' (2018) 29 European Journal of International Law 939, 955-959; Zimmermann (n 9) 219-220.

12 Stefan Barriga, 'The scope of the ICC jurisdiction over the crime of aggression: a different perspective.' Available at: $\quad$ https://www.ejiltalk.org/the-scope-of-icc-jurisdiction-over-the-crime-of-aggression-a-different-perspective/; Dapo Akande, 'The ICC Assembly of States Parties prepares to activate the ICC's jurisdiction over the crime of aggression: But who will be covered by that jurisdiction?’ Available at: https://www.ejiltalk.org/the-icc-assembly-ofstates-parties-prepares-to-activate-the-iccs-jurisdiction-over-the-crime-of-aggression-but-who-will-be-covered-bythat-jurisdiction/

13 Claus Kress, 'On the Activation of the ICC Jurisdiction over the Crime of Aggression' (2018) 16 Journal of International Criminal Justice 1, 13-14.
} 
ICC is an international organization, and the Rome Statute, its constituent instrument. The New York Activation Decision was adopted by the plenary organ of the ICC, and thus.$^{14}$ Thus, from an international institutional law perspective, the New York Activation Decision may be considered as "rules of the organization," which arguably may take precedence over the general rules of interpretation under the Vienna Convention. ${ }^{15}$ To better understand the New York Activation Decision as a means of treaty interpretation, it is thus necessary to consider both law of treaties and international institutional law analytical frameworks. As current literature appears to have only considered the law of treaties perspective, ${ }^{16}$ this article fills in the gap by considering the international institutional law aspects relevant to the Court as an international organization, and the Rome Statute as a constituent instrument.

Furthermore, the settlement of disputes with regard to questions - or disputes - on the interpretation of the Rome Statute on the crime of aggression has not yet been discussed in scholarly literature. Thus, this article also contributes an additional dimension to the scholarly debate by bringing forth dispute settlement perspectives to the activation of the ICC's jurisdiction over the crime of aggression at the ICC.

In light of the foregoing contributions to scholarly debate, this article is structured as follows. First, Section 2 sets out, and elaborates upon, the ambiguity with regard to the entry into force of the Kampala Amendments and the implications thereof for the jurisdictional regime of the ICC over the crime of aggression in State referrals and proprio motu investigations. As will be illustrated, the Rome Statute and the Kampala Amendments comprise different entry into force mechanisms respectively, leaving the question of which is the appropriate entry into force mechanism for the amendments on the crime of aggression. To shed light on this question, Section 3 discusses the interpretation of the Rome Statute in accordance with the rules of interpretation in Articles 31 and 32 of the VCLT. Within this framework, the New York Activation Decision is characterized as a subsequent agreement under Article 31(3)(a) to confirm the meaning of the Rome Statute in accordance with Article 31(1). In the event that an interpreter may not be convinced that the New York Activation Decision amounts to a subsequent agreement under Article 31(3)(a), it may be considered as subsequent practice in accordance with Article 32 as a supplementary means of

\footnotetext{
14 Article 112, Rome Statute.

15 Draft Conclusion 12, paragraph 4, ILC Conclusions on subsequent agreements and subsequent practice in relation to the interpretation of treaties, see Commentary to Draft Conclusion 12, paragraph 4, at p.104, para.40.

16 Akande and Tzanakopoulos (n 12); Andreas Zimmermann, 'A Victory for International Rule of Law? Or: All's Well That Ends Well?: The 2017 ASP Decision to Amend the Kampala Amendment on the Crime of Aggression' (2018) 16 Journal of International Criminal Justice 19; Darin Clearwater, 'When (and How) Will the Crime of Aggression Amendments Enter into Force? Interpreting the Rome Statute by Recognizing Participation in the Adoption of the Crime of Aggression Resolutions as "Subsequent Practice" under the VCLT' (2018) 16 Journal of International Criminal Justice 31.
} 
interpretation. Yet, another important aspect is also highlighted, which is that the New York Activation Decision is a Rule of the International Organization. Accordingly, it may prevail over Articles 31 and 32 of the VCLT with regard to the interpretation of the Rome Statute. As questions of interpretation are disputes about the interpretation, section 4 , considers the procedural aspects of dispute settlement pursuant to the Rome Statute, as well as the international legal order more generally.

The main submission of this article is that the New York Activation Decision confirms the amendment process pursuant to Article 121 of the Rome Statute for the entry-into-force of the Kampala Amendments, which in turn has the juridical effect that only nationals of States Parties that have ratified the amendments may be prosecuted at the ICC in State referrals and proprio motu investigations. In the event that one or more States Parties may disagree with the judicial function of the ICC in this regard, or with the interpretation or application of the Rome Statute, Article 119 provides a dispute settlement mechanism. Accordingly, it would appear that States Parties have somewhat more freedom of choice as to the means of settlement with respect to disputes other than the judicial function of the ICC.

The contributions of this article are threefold. First, by characterizing the New York Activation Decision as a subsequent agreement under Article 31(3)(a) of the VCLT, the legal effect of the interpretation espoused with regard to Article 121(5) may be considered as an authentic means of interpretation of the Rome Statute pursuant to Article 31(1). In the particular context when the interpreter is an organ of the ICC, the New York Activation Decision is a "Rule of the International Organization", which means that the paragraph that relates to the interpretation of the Rome Statute may constitute a "relevant rule" of interpretation. This has practical significance as the Court may only exercise jurisdiction over nationals that have ratified the Kampala Amendments in the absence of a Security Council referral. Secondly, this article has engaged with the recent work of the ILC in its Conclusions on Subsequent Agreement and Subsequent Practice, while also drawing to light the particular aspects of Constituent instruments. The New York Activation Decision, thus serves as a very relevant and apposite study for the law of treaties and international institutional law. The significance of the activation of the ICC's jurisdiction over the crime of aggression thus extends beyond international criminal law. In a similar vein, and thirdly; the discussion of specialist and generalist dispute settlement regimes with regard to the ICC is a topic which expands also beyond the crime of aggression. ${ }^{17}$

\footnotetext{
${ }^{17}$ Letter dated 9 July 2018 from the Permanent Representative of Kenya to the UN addressed to the SG, 'Request for an advisory opinion of the International Court of Justice on the consequences of legal obligations of States under different sources of international law with respect to immunities of Heads of State and Government and other senior officials' (18 July 2018) UN Doc A/73/144.
} 


\section{The Rome Statute and the Kampala Amendments:}

As mentioned in the introduction, the entry into force of the Kampala Amendments is directly relevant to the jurisdictional scope of the ICC over the crime of aggression. Yet, the ambiguity is premised on the entry into force mechanism - as will be demonstrated below, the Kampala Amendments appear to purport a different entry into force mechanism than the Rome Statute. Also, as will be demonstrated, State consent is inextricably linked to the entry-into-force mechanism of the Kampala Amendments, which in turn, has an effect on the jurisdictional regime of the Court over the crime of aggression. Thus, whether the Court may exercise jurisdiction over a national of a State Party for the crime of aggression is premised upon the way by which the Kampala Amendments have entered into force.

First, it is worth outlining the jurisdictional regime pursuant to Articles 15 bis and 15 ter of the Rome Statute, followed by examining the entry into force of these provisions.

\subsection{Exercise of jurisdiction over the crime of aggression}

In Kampala, two issues that remained unsolved from the prior negotiations formed the crux of the negotiations: first, the role of the UN Security Council as a pre-jurisdictional filter to determine the existence of an act of aggression prior to the commencement of an investigation or proceedings at the ICC; second, whether State consent of the alleged aggressor State is required in the event of proprio motu investigations and State referrals. ${ }^{18}$ Both issues pertained to the conditions for the exercise of jurisdiction, which led to a series of compromises between States Parties in this regard. The definition of the crime, which was formulated successfully in the preparatory work prior to Kampala, made its way without further discussion at the Review Conference into Article 8 bis. ${ }^{19}$ The conditions for the exercise of jurisdiction of the crime, on the other hand, involved reaching a consensus in relation to the two unresolved issues of State consent and the role of the Security Council. Ultimately, the compromise between States Parties resulted in two different

\footnotetext{
18 Wenaweser (n 3) 884; Niels Blokker and Claus Kress, 'A Consensus Agreement on the Crime of Aggression: Impressions from Kampala’ (2010) 23 Leiden Journal of International Law 889, 889-90; Barriga and Grover (n 10) 520.

${ }^{19}$ Barriga and Grover (n 10) 521-523.
} 
jurisdictional regimes pursuant to the trigger mechanism: ${ }^{20}$ Article 15 bis (State referrals and proprio motu investigations); Article 15 ter (Security Council referrals). ${ }^{21}$

Article 15 ter is considerably more straightforward than Article 15 bis, stipulating inter alia that the Court's jurisdiction over the crime of aggression can be triggered if the Security Council refers a situation to the Prosecutor of the ICC acting under Chapter VII of the UN Charter. ${ }^{22}$

By contrast, there are three key aspects to Articles 15 bis. First, Article 15 bis comprises a specific institutional regime: when the Prosecutor concludes that there is a reasonable basis to proceed with an investigation in respect of a crime of aggression, there is first the need to ascertain whether the Security Council has made a determination of an act of aggression committed by the State concerned. ${ }^{23}$ The Prosecutor may proceed with the investigation in respect of a crime of aggression where the Security Council has made such a determination; ${ }^{24}$ yet, where no determination is made by the Council within six months after the date of notification, the PreTrial Division may authorize the commencement of the investigation in respect of a crime of aggression, enabling the Prosecutor to proceed with the investigation in respect of this crime. ${ }^{25}$

Notably, this is a departure from the draft Statute for an International Criminal Court prepared by the ILC in $1994,{ }^{26}$ as well as the positions of the UK and France who had argued for the Security Council to serve as the exclusive jurisdiction filter for the crime of aggression. ${ }^{27}$ Thus, the issue of State consent of the alleged aggressor State for jurisdiction became a key point of principle, ${ }^{28}$ adding further complexity to the conditions for the exercise of jurisdiction and an already ambiguous entry-into-force mechanism of the Amendments.

\footnotetext{
${ }^{20}$ Article 13 of Rome Statute concerns the 'trigger' of the Court's jurisdiction: (a) [a] situation in which one or more of such crimes appears to have been committed is referred to the Prosecutor by a State Party; (b) A situation in which one or more of such crimes appears to have been committed is referred to the Prosecutor by the Security Council acting under Chapter VII of the Charter of the United Nations; or (c) The Prosecutor has initiated an investigation in respect of such a crime in accordance with article 15; See further William Schabas, The International Criminal Court: $A$ Commentary on the Rome Statute (Oxford University Press 2016) 371-379.; see also Roger O’Keefe, International Criminal Law (Oxford University Press 2015) 535-536.

${ }^{21}$ Barriga and Grover (n 10) 528-529.

22 Article 15 ter(1), Rome Statute.

23 Article 15bis (6), Rome Statute; the provision also stipulated: The Prosecutor shall notify the Secretary-General of the United Nations of the situation before the Court, including any relevant information and documents.

${ }^{24}$ Article 15 bis(7), Rome Statute.; Note that a determination of an act of aggression by the Security Council for the purposes of Article 15 bis is not substantively binding on the ICC as Articles 15 bis(9) and 15 ter(4) stipulate that: 'a determination of an act of aggression by an organ outside the Court shall be without prejudice to the Court's own findings under this Statute.' For a criticism of this, see Alain Pellet, 'Response to Koh and Buchwald's Article: Don Quixote and Sancho Panza Tilt at Windmills’ (2015) 109 American Journal of International Law 557, 563.

25 Article 15 bis(8), Rome Statute.

26 Article 23(2) reads 'A complaint of or directly related to an act of aggression may not be brought under this Statute unless the Security Council has first determined that a State has committed the act of aggression which is the subject of the complaint'.; see further, ILC Commentary at 39.; See also Niels Blokker, 'The Crime of Aggression and the United Nations Security Council' (2007) 20 Leiden Journal of International Law 867, 870-874.

27 ibid 878; Blokker and Kress (n 19) 894; Kress and von Holtzendorff (n 9) 1212. For a background on the varying positions in the SWGCA, see Blokker (n 27) 876-878.

28 Wenaweser (n 3) 884-885.
} 
Pursuant to Article $15 \operatorname{ter}$ (1), it will suffice for the Security Council to refer a situation to the ICC. Thus, the institutional regime requiring a determination of an act of aggression as a jurisdictional filter prior to the initiation of investigations is only applicable to State referrals and proprio motu investigations.

Secondly, Article 15 bis(5) stipulates: 'in respect of a State that is not a party to this Statute, the Court shall not exercise its jurisdiction over the crime of aggression when committed by that State's nationals or on its territory.' By contrast, the ICC may exercise jurisdiction over the crime of aggression pursuant to Security Council referrals, irrespective if whether the State concerned has accepted the Court's jurisdiction in this regard. ${ }^{29}$ Thus, non-States Parties are entirely excluded from the jurisdiction of the ICC over the crime of aggression in the absence of a Security Council referral. $^{30}$

Notably, this departs from the jurisdictional regime of the ICC over the other crimes in Article 5(1) of the Rome Statute as Article 12(2)(b) stipulates that the Court may exercise its jurisdiction over a national of non-State Party if the crime was committed on the territory of a State that has accepted the jurisdiction of the Court. ${ }^{31}$ It can be inferred that this decision was made on the premise of upholding State consent. ${ }^{32}$

Thirdly, Article 15 bis(4) stipulates:

The Court may, in accordance with article 12, exercise jurisdiction over a crime of aggression, arising from an act of aggression committed by a State Party, unless that State Party has previously declared that it does not accept such jurisdiction by lodging a declaration with the Registrar. The withdrawal of such a declaration may be effected at any time and shall be considered by the State Party within three years.

The reference to Article 12 merits further consideration. Article 12(1) of the Rome Statute stipulates that a State which becomes a Party to this Statute thereby accepts the jurisdiction of the Court with respect to the crimes referred to in article 5 (which includes the crime of aggression).

${ }^{29}$ Understanding 2 in Annex III of Resolution Res RC/Res.6.

30 Japan has said criticized Article 15 bis as 'an amendment which unjustifiably solidifies blanket and automatic impunity of nationals of non-State Parties: a clear departure from the basic tenet of article 12 of the Statute; see Statement by Japan; Statements by States Parties in explanation of position before the adoption of resolution RC/Res.6, on the crime of aggression, contained in Annex VII, Review-Conference-official-records, RC/11; The position of Japan has also been addressed in Kress and von Holtzendorff (n 9) 1212; Zimmermann (n 9) 221-223.

${ }^{31}$ Dapo Akande, 'The Jurisdiction of the International Criminal Court over Nationals of Non-Parties: Legal Basis and Limits' (2003) 3 Journal of International Criminal Justice 618, 626.

32 The President of the Review Conference has reflected that the exclusion of non-States Parties altogether, together with a possibility for States Parties to opt-out of the Court's jurisdiction had emerged as a compromise to the issue of state consent, and acknowledges the 'wholesale exemption for non-states parties', as a significant compromise, see Wenaweser (n 3) 885, 887.. 
Article 12(2) suggests that jurisdiction rationae materiae over the crime is premised on either the nationality or territoriality principle of jurisdiction of a State that has accepted the Court's jurisdiction. Yet, the explicit reference in Article 15 bis(4) to 'State Party' implies that the Court cannot exercise jurisdiction over a crime of aggression arising from an act of aggression committed by a non-State Party. This is further affirmed by the next provision, which as mentioned above, excludes non-State Parties entirely from the jurisdiction of the Court on either the nationality or territoriality principle. Thus, to uphold the nationality or territoriality principle inherent within Article 12(2), it is suggested that pursuant to Article 15 bis(4) a national of a non-ratifying State Party can be prosecuted for the crime of aggression arising from an act of aggression against a ratifying State Party; or a national of a ratifying State Party can be prosecuted for the crime of aggression arising from an act of aggression against a non-ratifying State Party.

Notably, Article 15 bis(4) provides an opt-out declaration for States Parties who do not accept the Court's jurisdiction over the crime of aggression. The negotiation history suggests that the optout declaration was created to reconcile the positions of States who wished to apply the existing jurisdictional regime under Article 12 to the crime of aggression and those in favor of a strict consent-based regime for jurisdiction. ${ }^{33}$ This feature of Article 15 bis(4) suggests that the jurisdictional regime over the crime of aggression in the case of State referrals and proprio motu investigations is premised on a tacit consent/opt-out regime. Accordingly, it is presumed that State Parties have accepted the Court's jurisdiction over the crime of aggression in the absence of a Security Council referral so long as they have not opted-out.

The opt-out declaration in Article 15 bis(4) is central to the debate with regard to how State consent to jurisdiction should be demonstrated: whether consent needs to be express, i.e. in the form of a ratification of the Kampala Amendments; or whether consent is implied unless the State Party has 'opted-out' of the Court's jurisdiction over this crime. The latter suggests a tacit consent by States Parties of the Court's jurisdiction of the crime.

2.2. The entry into force of the Kampala Amendments

The ASP had stipulated that the Amendments shall enter into force in accordance with Article 121(5). ${ }^{34}$ According to Article 121(5):

\footnotetext{
${ }^{33}$ Kress and von Holtzendorff reflect that 'to not require the ratification of the alleged aggressor State Party, but to grant that state the right to opt out, amounts to a 'softened consent-based regime' that is situated somewhere between the two poles and is, therefore, a suitable basis from which to reach a compromise. Kress and von Holtzendorff (n 9) 1213.

${ }_{34}$ Operative paragraph 1, Resolution RC/Res.6; For a background on the negotiations for entry-into-force, see Barriga and Grover (n 10) 523-525.
} 
Any amendment to articles 5, 6, 7 and 8 of this Statute shall enter into force for those States Parties which have accepted the amendment one year after the deposit of their instruments of ratification or acceptance. In respect of a State Party which has not accepted the amendment, the Court shall not exercise its jurisdiction regarding a crime covered by the amendment when committed by that State Party's nationals or on its territory.

In the preparatory work of the Kampala Amendments, Article 121(5) was subject to two different understandings by States Parties: i) a negative interpretation; ii) a positive interpretation. ${ }^{35}$ The former reads Article 121(5) in its entirety with the effect that jurisdictional regime over the crime of aggression will not apply towards a national, or territory, of a State Party that has not ratified the amendments, whilst the latter reads the second sentence of Article 121(5) in the context of the entirety of the Rome Statute in a manner that limits its effect on the existing jurisdictional regime. ${ }^{36}$ In light of the positive interpretation, a non-ratifying State Party attains the same position as a non-State Party with respect to Article 12(2) of the Rome Statute, whereby the Court may exercise jurisdiction provided it is satisfied of a nationality or territoriality principle. ${ }^{37}$

With regard to the Kampala Amendments, two interpretations largely based on the aforementioned interpretations have been put forward with respect to how Article 15 bis(4) should be read in light of Article 121(5).

One interpretation is premised on the demarcation of Article 121(5). The first sentence: 'any amendment to articles 5, 6, 7 and 8 of this Statute shall enter into force for those States Parties which have accepted the amendment one year after the deposit of their instruments of ratification or acceptance' is read in isolation from the second sentence, and serves as the entry into force mechanism for the Kampala Amendments. ${ }^{38}$ Blokker and Barriga have suggested that Article 12(1) serves as the lex specialis, as it refers specifically to States Parties accepting the Court's jurisdiction over the crime of aggression, while the second sentence of Article 121(5) does not specifically refer to the crime of aggression, but relates more generally to amendments to articles 5, 6, 7 and $8 .{ }^{39}$ By considering Article 12(1) as the lex specialis, Article 15 bis(4) which refers to Article 12 would thus prevail over the second sentence of Article 121(5) with respect to the jurisdictional regime over

\footnotetext{
35 Kress and von Holtzendorff (n 9) 1196-1198; Zimmermann (n 9) 217-220.

36 Reisinger Coracini (n 9) 705-713,718; Kress and von Holtzendorff (n 9) 1197-1198.

${ }^{37}$ Kress and von Holtzendorff (n 9) 1197-1198; Reisinger Coracini (n 9) 711-713. See also Alain Pellet, 'Entry into Force and Amendment of the Statute' in Antonio Cassesse, Paola Gaeta and John RW. Jones (eds), The Rome Statute of the International Criminal Court: A Commentary (Oxford University Press 2002) 182.

38 Kress and von Holtzendorff (n 9) 1214; Barriga and Blokker (n 10) 627-628.

39 Barriga and Blokker (n 11) 666-667. For a criticism of this position see Akande and Tzanakopoulos (n 12) 957.; For a different view on the lex specialis, see Zimmermann (n 9) 212.
} 
the crime of aggression. Thus, so long as one State Party has ratified the Kampala Amendments, the Court may apply jurisdiction over the crime pursuant to the territoriality or nationality principles of jurisdiction with the caveat that the alleged aggressor State Party has not opted-out of jurisdiction. ${ }^{40}$

The alternative interpretation upholds that Article 121 is the lex specialis; ${ }^{41}$ and Article 121(5) is applicable in its entirety. ${ }^{42}$ Thus, the Kampala Amendments enter into force for States Parties according to the first sentence of Article 121(5), while the jurisdiction over the crime of aggression is governed by the second sentence: in respect of a State Party which has not accepted the amendment, the Court shall not exercise its jurisdiction regarding a crime covered by the amendment when committed by that State Party's nationals or on its territory.' The ordinary meaning of the second sentence suggests that the ICC may only exercise jurisdiction if both the intended victim State Party and alleged aggressor State Party have ratified the Kampala Amendments. ${ }^{43}$ Thus, contrary to the view above, this jurisdictional regime appears to be an 'optin' regime, as opposed to a tacit consent/opt-out regime. ${ }^{44}$ States Parties nevertheless are not precluded from opting-out from the Court's jurisdiction over this crime, even if they do not ratify the Amendments. ${ }^{45}$

The underlying question is whether the jurisdictional regime of the ICC over the crime of aggression in the absence of a Security Council is premised on Article 15 bis(4) or Article 121(5). Although this may appear to be a highly technical question of law of treaties, there is also a practical element whereby the first position would espouse a broader scope of jurisdiction ("broader position"), while the second position gives rise to a narrower scope of jurisdiction ("narrower position”).

Thus, either position has a practical effect with regard to the powers of the ICC to exercise jurisdiction over the crime of aggression. Put simply, the broader position suggests that the ICC may exercise jurisdiction over the crime of aggression if either the aggressed State or the aggressor State have ratified the Kampala amendments; and the latter has not opted out. ${ }^{46}$ The narrower position stipulates that the ICC may only exercise jurisdiction if both aggressed and aggressor States have ratified the amendments; and the latter has not opted out. ${ }^{47}$

\footnotetext{
${ }^{40}$ Kress and von Holtzendorff (n 9) 1214.

41 Zimmermann (n 9) 212. See also Akande and Tzanakopoulos (n 12) 952.

42 Akande and Tzanakopoulos (n 12) 957.

${ }^{43}$ Zimmermann suggests that 'only on the basis of Article 121(5) ICC Statute in its 'negative understanding' interpretation that any amendment to the Statute providing for the crime of aggression could be adopted and eventually enter into force', Zimmermann (n 9) 219-220.

${ }^{44}$ For a criticism of this view, see Barriga and Blokker (n 11) 663.

45 Kress and von Holtzendorff (n 9) 1213.

46 See Table 6.2, Wong (n 11) 208.

47 See Table 6.1, ibid 204.
} 
To shed light on which position comprises the better interpretation, it is necessary to consider the amendment process of the Kampala Amendments. The starting point is Article 121 of the Rome Statute, which governs amendments. As discussed above, paragraphs (4) and (5) are relevant to the entry into force for amendments and were considered in the course of negotiations with the latter ultimately chosen. Article 121(5) in its entirety, if read in accordance with Article 121 as the ordinary amendment process, would appear consistent with the narrower position. The broader position, on the other hand, demarcates Article 121(5) with the effect of applying only the first sentence exclusively to the entry into force of the amendments, and departs from Article 121 in its entirety. This creates a sui generis amendment to the Rome Statute. The question thus arises whether the amendment process of the Kampala Amendments stems from the ordinary amendment process as adopted in Rome or the sui generis amendment process as adopted in Kampala. This shifts the present inquiry to ascertain whether the ASP had the powers to adopt the Kampala Amendments under a sui generis amendment process.

\subsection{The powers of the ASP in Kampala to amend the Rome Statute}

From an international institutional law standpoint, the ASP have the power to amend the Rome Statute on the crime of aggression, particularly with regard to the definition and the conditions for the exercise of jurisdiction as mandated by former Article 5(2). As discussed above, the question of whether the broader position or narrower position should prevail is premised on the amendment process of the Rome Statute and how the Kampala Amendments should enter into force. The issue that merits further consideration is whether the powers of the ASP to amend the Statute is limited to the amendment process pursuant to Article 121, or if States Parties may amend the amendment process, and thus the Rome Statute, by mutual agreement. ${ }^{48}$

Resolution RC/Res.6 as adopted by consensus in Kampala, stipulated that the amendments shall enter into force in accordance with Article 121(5); while the narrower position in relation to the Court's jurisdiction over the crime of aggression is premised on the application of Article 121(5) in its entirety. Thus, the question is not whether States Parties have departed from the amendment process as stipulated in the Rome Statute, but rather whether Article 121(5) itself can be amended. There are two possibilities in light of the latter: either a provision in the Rome Statute allows this; or States Parties have tacitly agreed to amend Article 121(5). Both possibilities are now examined.

48 Schermers and Blokker (n 4) 767. See also Zimmermann (n 9) 211. 
Article 121 is the only provision in the Rome Statute governing amendments. ${ }^{49}$ In assessing whether the Rome Statute stipulates otherwise, the obvious port of call is to return to former Article 5(2). The text of former Article 5(2) does not mention an amendment process specific to the crime of aggression, but refers to Article 121 in its entirety. Yet, former Article 5(2) expressly provides the ASP with the mandate to define the crime and set out the conditions under which the Court shall exercise jurisdiction with respect to this crime. The question is whether this mandate also provides States with the power to create an amendment process that they deem fit for the purposes of adopting the definition and conditions of the crime.

Two views may prevail. First, and the more restrictive view, purports that the powers conferred by former Article 5(2) are limited to the definition and conditions for the exercise of jurisdiction as there is no mention of a special amendment procedure for the Kampala Amendments. ${ }^{50}$ The specific reference to Article 121 is used in further support of this view. Yet, as discussed above, the specific reference in former Article 5(2) to Article 121 raised ambiguity in the course of the preparatory work and negotiations and propelled States to consider a special entry-into-force mechanism as a practical solution in light of two seemingly incompatible provisions. ${ }^{51}$ Thus, the second view suggests that a sui generis amendment process was necessary for the ASP to carry out the function of adopting amendments that define the crime and the conditions under which the Court may exercise jurisdiction. Accordingly, the mandate in former Article 5(2) was broad enough to provide the ASP with all the powers it deemed necessary to negotiate and adopt amendments on 'all aspects' relevant to the definition of the crime of aggression and the conditions for the exercise of jurisdiction, ${ }^{52}$ with the only caveat that the amendments are to be consistent with the UN Charter. This would thus comprise the powers to create a sui generis amendment process to give effect to the definition of the crime or conditions for the exercise of jurisdiction.

Even if it is not entirely clear whether former Article 5(2) provided the ASP with the powers to create a suigeneris amendment process, the view that States Parties may tacitly amend a treaty is generally accepted, ${ }^{53}$ e.g. Frowein takes the position that 'all the parties to a treaty, by unanimous decision, can override all limitations contained in specific treaty provisions, ${ }^{54}$ and it is 'theoretically

\footnotetext{
49 Zimmermann (n 17) 212.

50 Akande and Tzanakopoulos (n 12) 951.

${ }^{51}$ Kress and von Holtzendorff (n 9) 1199; Barriga, Danspeckgruber and Wenaweser (n 9) 51; Reisinger Coracini (n 9)

716. But see Akande and Tzanakopoulos (n 12) 951.

52 Barriga and Blokker (n 11) 668.

${ }^{53}$ Commentary to Draft Conclusion 11(2), ILC Conclusions p.84, para.8.

54 Jochen A Frowein, 'Are There Limits to the Amendment Procedures in Treaties Constituting International Organisations?', Liber Amicorum: Professor Ignaz Seidl-Hobenveldern in honour of bis 80th birthday (Kluwer Law International 1998) 204.
} 
possible to argue that states, under those circumstances would at the same time tacitly amend the rules concerning the amendment procedure. ${ }^{55}$ It is arguable that the ASP had tacitly amended the amendment process in Article 121..$^{56}$

Although States Parties did not clearly or expressly indicate any intention to amend Article 121, a closer look at Articles 15 bis and 15 ter suggest a departure from the amendment provisions in the Rome Statute including Article 121(5). ${ }^{57}$ Articles 15 bis(2) and $15 \operatorname{ter}(2)$ stipulate the quorum of thirty States Parties to accept or ratify the Amendments, while Articles $15 \operatorname{bis}(3)$ and $15 \operatorname{ter}(3)$ which require an activation decision to be taken after 1 January by the same majority of States Parties as is required for the adoption of an amendment. It may indeed appear that the effect of these common articles are that the amendments on the crime of aggression enter into force for each ratifying State Party individually before the amendments enter into force for the Court. ${ }^{58}$ This would suggest that entry into force is entirely separate from the activation of the Court's exercise of jurisdiction. ${ }^{59}$

Both aforementioned common articles as conditions for the exercise of jurisdiction depart from the amendment process of the Rome Statute, as Article 121 does not mention a quorum of the acceptance or ratification by 30 States Parties or an additional activation decision subject to the same majority of States Parties as is required for the adoption of an amendment. Yet, this 'formula for delayed activation' was devised by the President of the Review Conference as a means to obtain a consensus, ${ }^{60}$ as part of the powers conferred to the ASP by former Article 5(2) to adopt amendments on the definition of the crime of aggression and conditions under which the Court may exercise over this crime.

Thus, States Parties had relied on these powers to create conditions for the exercise of the Court's jurisdiction over the crime are not entirely consistent with Article 121 of the Rome Statute. ${ }^{61}$ It can be inferred that a sui generis amendment process must be in place in order to give effect to these conditions. The argument can be made that States Parties tacitly agreed to amend the amendment process to enable delaying the activation of the Court's jurisdiction over the crime of aggression as one of the conditions for the exercise of jurisdiction. This would mean that Article

\footnotetext{
55 ibid.

56 But see Akande and Tzanakopoulos (n 12) 953.

57 Zimmermann (n 9) 220.

${ }^{58}$ These States Parties have ratified the Kampala Amendments before the Activation Decision : Andorra; Argentina; Austria; Belgium; Botswana; Chile; Costa Rica; Croatia; Cyprus; Czech Republic; El Savador; Estonia; Finland; Georgia; Germany; Iceland; Latvia; Liechtenstein; Lithuania; Luxembourg; Malta; Netherlands Panama; Poland; Portugal; Samoa; San Marino, Slovakia; Slovenia; Spain; State of Palestine; Switzerland; The former Yugoslav Republic of Macedonia; Trinidad and Tobago; Uruguay; Available at https://treaties.un.org/Pages/ViewDetails.aspx?src=TREATY\&mtdsg no=XVIII-10-b\&chapter=18\&lang=en.

${ }_{59}$ Barriga and Blokker (n 10) 627-628.

${ }^{60}$ Wenaweser (n 3) 887.

${ }^{61}$ But see, Zimmermann (n 9) 227.
} 
121 was not complied with in its entirety. Accordingly, it not entirely persuasive to suggest that Article 121(5) must apply in its entirety for the purposes of consistency with the provision in the Rome Statute governing amendments. If States Parties have tacitly amended the Rome Statute to allow a delay in the activation of the Court's jurisdiction as a condition for the exercise of jurisdiction as mandated by former Article 5(2), then a reading of Article 121(5) that disregards the effect of the second sentence on the consequences on jurisdiction pursuant to the entry-into-force is tenable on the basis that the amendment process of the Kampala Amendments has departed from Article 121 in its entirety.

It is perhaps worth clarifying that both divergent positions with respect to how Article 15 bis(4) should be read in light of Article 121(5) uphold consent of the alleged aggressor State. The issue is the manner in which consent is expressed. The broader position is premised on a tacit consent/opt-out framework, whereby States Parties to the Rome Statute have accepted the jurisdiction of the Court over the crime of aggression, ${ }^{62}$ unless they opt-out pursuant to Article 15 bis(4). The narrower position holds that consent is expressed by way of a formal ratification, and refer to Article 40(4) of the VCLT: ' $t$ ] he amending agreement does not bind any State already a party to the treaty which does not become a party to the amending agreement.' Yet, the VCLT is subsidiary to the Rome Statute in the particular context of consent, ${ }^{63}$ as it is for States Parties to decide on the mode of expressing consent. ${ }^{64}$ Thus, if States Parties wish to create a tacit consent/opt-out framework, this is entirely within their powers and discretion. For the foregoing reasons, whichever jurisdictional position ultimately prevails, State consent is upheld.

\section{Interpreting the Rome Statute on the crime of aggression}

\subsection{The ICC and Kompetenz-Kompetenz}

The principle of Kompetenz-Kompeten z applies to the ICC, as stipulated in Article 19(1) of the Rome Statute: '[t]he Court shall satisfy that it has jurisdiction in any case brought before it. ${ }^{65}$ Accordingly, the ICC also has the inherent jurisdiction to resolve disputes in relation to the

\footnotetext{
62 Article 12(1), Rome Statute.

${ }^{63}$ As per Judge Jessup, "International law, not being a formalistic system, holds States legally bound by their undertakings in a variety of circumstances.', Separate Opinion of Judge Jessup, South West Africa Cases (Ethiopia v. South Africa; Liberia v. South Africa), Preliminary Objections, Judgment of 21 December 1962: I.C. J. Report; 1962, p. 319, p.411.

64 Malgosia Fitzmaurice, 'Consent to Be Bound -Anything New under the Sun?' (2005) 74 Nordic Journal of International Law 483, 484.

65 Situation in Uganda, Decision on the Prosecutor's Application that the Pre-Trial Chamber Disregard as irrelevant the Submission Filed by the Registry on 5 December 2005, Pre-Trial Chamber II, 9 Mar.2006, paras.22-23; Prosecutor $v$ Kony et al., Decision of Admissibility of the Case under Article 19(1) of the statute, Pre-Trial Chamber II, ICC-02/04-
} 
exercise of its jurisdiction, ${ }^{66}$ or judicial function, ${ }^{67}$ with regard to the crime of aggression. ${ }^{68}$ From an international institutional law perspective, the Kompetenz-Kompetenz of the ICC is indicative of the separate competences of the ASP and the Court. In the context of the crime of aggression, the Kompetenz-Kompetenz of the Court to satisfy itself of its interpretation of Articles 15 bis and 15 ter is indicative of its judicial independence from the ASP. ${ }^{69}$

3.2. The general rule of means of treaty interpretation and the Vienna Convention on the Law of Treaties

The preceding analysis has put forward that the ASP in Kampala tacitly amended Article 121 of the Rome Statute. Accordingly, the jurisdictional regime over the crime of aggression in a case of State referrals and proprio motu investigations is premised on the tacit consent/opt-out regime pursuant to Article 15 bis(4). Yet, it is for the Court, as the interpreter, to interpret the Rome Statute with regard to the provisions on the crime of aggression. Article 31 of the VCLT, is the general rule of interpretation, which stipulates, in paragraph 1:

A treaty shall be interpreted in good faith in accordance with the ordinary meaning to be given to the terms of the treaty in their context and in the light of its object and purpose.

'Context' according to paragraph 2, for the purposes of interpretation of a treaty, comprises [in addition to the text]:

(a) Any agreement relating to the treaty which was made between all the parties in connexion with the conclusion of the treaty;

(b) Any instrument which was made by one or more parties in connexion with the conclusion of the treaty and accepted by the other parties as an instrument related to the treaty.

01/05-37710. Mar.2009, para.45; Prosecutor v Bemba, Decision Pursuant to Article 61(7)(a) and (b) of the Rome Statute on the Charges of the Prosecutor Against Jean-Pierre Bemba Gombo, Pre-Trial Chamber II, 15 Jun.2009, ICC-01/0501/08-424, para.23.

66 Articles 19, Rome Statute.

${ }^{67}$ Article 119(1), Rome Statute. This was affirmed by the ICJ in Nuclear Tests (Australia v. France), Judgment, I.C.J. Reports 1974, p. 253, para.23.

68 Zimmermann (n 9) 226.

${ }^{69}$ OP3 of the New York Activation Decision reaffirmed paragraph 1 of article 40 and paragraph 1 of article 119 of the Rome Statute in relation to the judicial independence of the judges of the Court. 
Resolution RC/Res.6 comprises: amendments on the crime of aggression; Elements of the Crime and Understandings. It is likely that this Resolution will be considered together with the Rome Statute. Thus, the ambiguity with respect to Article 15 bis(4) and Article 121(5) will arise. The New York Activation Decision is a decision adopted within the framework of a Conference of States Parties, ${ }^{70}$ which attempts to provide meaning to Articles 15 bis(4) and Article 121(5) of the Rome Statute. ${ }^{71}$ The apposite question is whether the New York Activation Decision will also be considered as part of the 'context' in Article 31(2); or 'to be taken into account together with context' pursuant to Article 31(3) of the VCLT:

(a) Any subsequent agreement between the parties regarding the interpretation of the treaty or the application of its provisions;

(b) Any subsequent practice in the application of the treaty which establishes the agreement of the parties regarding its interpretation.

In the event that the New York Activation Decision does not fall under Article 31(2) or 31(3)(a), there is also the possibility that the Decision may amount to subsequent practice as a supplementary means of interpretation pursuant to Article 32 of the VCLT. ${ }^{72}$ Yet, even though States Parties acted in their capacity as States Parties to a multilateral treaty, the decision was also adopted by the ASP as the plenary organ of the ICC. Thus, the New York Activation Decision may be considered as a "Rule of the Organization". 73

\subsection{The New York Activation Decision as a subsequent agreement on interpretation}

The key features of the New York Activation Decision are the operative paragraphs that decide to activate the Court's jurisdiction over the crime of aggression as of 17 July $2018 ;^{74}$ and confirm the narrow position in relation to the interpretation of the Court's jurisdiction over the crime of aggression. ${ }^{75}$ The latter, i.e. Operative Paragraph 2 (“OP2”) is worth producing in full:

\footnotetext{
70 Draft Conclusion 11, paragraphs 1 and 2, ILC Conclusions.

71 Preamble paragraph 5, Resolution ICC-ASP/16/Res.5 (2017).

72 Draft Conclusion 4, paragraph 3, and Draft Conclusion 12, paragraph 1, ILC Conclusions

${ }^{73}$ Christiane Ahlborn, 'The Rules of International Organizations and the Law of International Responsibility' (2011)

8 International Organizations Law Review 397, 424-428.

74 Operative paragraph 1, Resolution ICC-ASP/16/Res.5.

75 Operative paragraph 2, Resolution ICC-ASP/16/Res.5.
} 
[The ASP] Confirms that, in accordance with the Rome Statute, the amendments to the Statute regarding the crime of aggression adopted at the Kampala Review Conference enter into force for those States Parties which have accepted the amendments one year after the deposit of their instruments of ratification or acceptance and that in the case of a State referral or proprio motu investigation the Court shall not exercise its jurisdiction regarding a crime of aggression when committed by a national or on the territory of a State Party that has not ratified or accepted these amendments.

OP2 appears to reflect Article 121(5) in its entirety, and is consistent with the narrower position of interpretation whereby the second sentence of Article 121(5) prevails over Article 15 bis(4) with regard to the jurisdiction of the Court over the crime of aggression in a case of State referral or proprio motu investigation. Thus, it would appear the New York Activation Decision upholds the amendment process in Article 121 of the Rome Statute. ${ }^{76}$

The legal effect of this decision, may 'embody, explicitly or implicitly, ${ }^{77}$ a 'subsequent agreement between the parties regarding the interpretation of the treaty or the application of its provisions' pursuant to Article 31(3)(a) VCLT. It is important to note that the present inquiry differs from the one above in section 2.3. with regard to tacit amendment by States Parties, as it is generally 'presumed that the parties to a treaty, by an agreement or a practice in the application of the treaty, intend to interpret the treaty, not to amend or to modify it. ${ }^{, 78}$

According to the ILC in its Conclusions, in the event that the New York Activation Decision amounts to a subsequent agreement under Article 31(3)(a), OP 2 may be considered as an authentic means of interpretation. ${ }^{79}$ The underlying question is whether the New York Activation Decision 'expresses agreement in substance between the parties regarding the interpretation of a treaty. ${ }^{80}$ With the emphasis on the substance of the agreement, the form and procedure by which the decision was reached is of lesser significance, 'including adoption by consensus. ${ }^{81}$ In this light,

\footnotetext{
76 Zimmermann (n 17) 20-21.

${ }_{77}$ Draft Conclusion 11, paragraph 2, ILC Conclusions.

${ }_{78}$ Draft Conclusion 7, paragraph 3, ILC Conclusions.

79 Draft Conclusion 3, ILC Conclusions; See also, Draft Conclusion 2, paragraph 5, and Draft Conclusion 10 , paragraph 1.; Note that The ILC has commented that 'the characterization of subsequent agreements and subsequent practice of the parties under article 31, paragraph 3(a) and (b), as "authentic means of interpretation" does not, however, imply that these means necessarily possess a conclusive effect.[...] For this reason, and notwithstanding the suggestions of some commentators, subsequent agreements and subsequent practice that establish the agreement of the parties regarding the interpretation of a treaty are not necessarily legally binding.', Commentary to ILC Conclusions, p.24, para.4.

${ }^{80}$ Draft Conclusion 11, paragraph 3, ILC Conclusions.

${ }^{81}$ Draft Conclusion 11, paragraph 3, ILC Conclusions.; The ICJ has nevertheless observed in relation to consensus, that the Recommendations made by the International Whaling Commission (IWC), which take the form of resolutions, 'which take the form of resolutions, are not binding. However, when they are adopted by consensus or
} 
the ILC has commented that 'consensus is not a concept that necessarily indicates any particular degree of agreement on substance; ${ }^{82}$ and that it follows that adoption by consensus is not a sufficient condition for an agreement under article 31, paragraph (3) (a) or (b) to be established. ${ }^{, 83}$ Thus, according to the ILC Conclusions, consensus is not an automatic premise that New York Activation Decision amounts to a subsequent agreement. Instead, the underlying factor is whether all States Parties have agreed in substance to the interpretation of the Rome Statute as stipulated in OP2 ${ }^{84}$ However, it is difficult to say with certainty that all States Parties agreed substantively on the interpretation stipulated in OP2, and that the latter demonstrates 'objective evidence of the understanding of the parties as to the meaning of the treaty' as an authentic means of interpretation. ${ }^{85}$

Prior to the ASP Session in New York, States Parties had submitted papers expressing different views with regard to the jurisdiction of the ICC over the crime of aggression. ${ }^{86}$ At the ASP session itself, an option was for States Parties to simply decide to activate the Court's jurisdiction over the crime of aggression. ${ }^{87}$ Accordingly, the Court would satisfy itself of its jurisdiction over the crime of aggression, thereby resolving the dispute between States Parties. Yet, Kress informs that "many of those States Parties supporting the "restrictive position" did not wish to take the risk that the Court might, after the activation of its jurisdiction, decide not to follow their view. They rather sought to have their position accepted and confirmed by all States Parties

by a unanimous vote, they may be relevant for the interpretation of the Convention or its Schedule.' Whaling in the Antarctic (Australia v Japan, New Zealand Intervening), Judgment 31 March 2014, ICJ Reports (2014), 226, at para.46.

82 Commentary to draft Conclusion 11, paragraph 3, p.90, para.30.

${ }^{83}$ Commentary to draft Conclusion 11, paragraph 3, p.91, para.31.

See also Comments on Some Procedural Questions issued by the Office of Legal Affairs of the United Nations Secretariat in accordance with General Assembly resolution 60/286 of 8 September 2006, paper prepared by the Secretariat; as reproduced in Commentary to draft Conclusion 11, para.3, at p.91.

${ }^{84}$ Commentary to draft Conclusion 11, paragraph.3, p.92, para.38.

85 draft Conclusion 3, ILC Conclusions.

${ }^{86}$ For the narrower position, see Paper submitted by Canada, Colombia, France, Japan, Norway and United Kingdom (March 2017) on Jurisdiction of the International Criminal Court over the crime of aggression amendments adopted in Kampala, Report on the Facilitation on the Activation of the Jurisdiction of the International Criminal Court over the crime of aggression (ICC-ASP/16/24) 27 November 2017 (hereinafter "Report on the facilitation of activation"), Annex II, p.15, para.2 ('It is our clear view that as a matter of treaty law, and contrary to an opinion which has been expressed, the Court cannot exercise jurisdiction over nationals of a State or on the territory of a State unless that State accepts or ratifies the aggression amendments. It is essential that this point is clarified before any decision is taken to activate the crime of aggression'); For the broader position, see Paper submitted by Liechtenstein (April 2017), Report on the facilitation of activation, Annex II, p.21-22, paras.9-14; and Paper submitted by Argentina, Botswana, Samoa, Slovenia and Switzerland (August 2017), Report on the facilitation of activation, Annex II, p.25 (The only remaining action the Kampala Review Conference gave the ASP to consider is "turning the light on". Adopting an operative paragraph according to which the ASP 'decides to activate the jurisdiction of the ICC over the crime of aggression' is all that is necessary.').

87 See Operative paragraph 1 of Elements of an activation decision, presented by Switzerland, ,Report on the facilitation on the activation, Annex III, ICC-ASP/16/24; see also Nikolas Stürchler, "The Activation of the Crime of Aggression in Perspective', available online at )https:// www.ejiltalk.org/the-activation-of-the-crime-of-aggressionin-perspective/), and Kress (n 14) 9-10; Clark, 'Exercise of Jurisdiction over the Crime of Aggression (International Criminal Court)' (n 10) para.44. 
as part of the resolution accompanying the activation decision. ${ }^{, 88}$ Thus, another option was a bridge of sorts between both positions that allowed "both campus to maintain their respective legal positions and of providing any State Party that supported the "restrictive position", if it so desired, with a legal avenue for jurisdictional protection in the event that the Court were to embrace the more "permissive position." 89

Kress further points out that the UK and France were adamant that 'all States Parties should accept the "restrictive position as part of the ASP resolution accompanying the activation decision. ${ }^{90}$ This created an 'extremely difficult situation', ${ }^{91}$ as a vote in lieu of consensus brought forth uncertainty with regard to whether the ICC's jurisdiction over the crime of aggression would be activated. ${ }^{92}$ Although adoption by vote was technically possible in light of Article 15 bis(3) and $15 \operatorname{ter}(3)$ calling for a two-third majority, it would appear that decision-making by consensus was the sounder political choice. ${ }^{93}$ Yet, to obtain a consensus in light of the adamancy of France and UK to include a provision accompanying the provision activating the jurisdiction, States Parties holding onto the broader position had to make significant concessions in this regard. ${ }^{94}$

Thus, the consensus for the New York Activation Decision is not necessarily representative of States Parties agreeing with the position in OP2; but rather States Parties who held the opposing position did not wish to block the consensus. ${ }^{95}$ Furthermore, upon the adoption of the New York Activation Decision, certain States Parties had expressed their legal positions which affirmed their views in relation to the broader position - and not, as stipulated in OP2. ${ }^{96}$ So, it would seem in light of the ILC Conclusions, the differing positions by the States Parties and the explanation after

\footnotetext{
${ }^{88}$ Kress (n 14) 10.

89 ibid. Kress elaborates that one proposed variant was 'to have all States Parties agree that the communication by a State Party of its "restrictive position" to the Registrar should be treated by the Court as a declaration, as referred to in Article 15 bis(4) of the ICC statute, if the Court were to embrace the "more permissive position", which was a draft transmitted by Germany to the Austrian Facilitator, and occasionally referred to as the 'Non-German Non-Paper'; the other proposed variant, developed by Brazil, Portugal and New Zealand, allowed 'any State Party, which so desired, to be placed on a list established by the President of the ASP and to be transferred to the Registrar, and to have the ASP decide that the Court shall not exercise its jurisdiction over the crime of aggression over nationals or on the territory of any such State Party', p.10-11.

90 ibid 11.

91 ibid.

92 Stürchler points out that ' $[. .$.$] no less than 82$ positive votes were necessary to achieve activation. This was a tall order, given that barely 100 delegations were represented in the room and given that since its establishment in 2002, the Assembly has never voted on a resolution. Presumably, only few delegations had instructions for a possible vote. [...] The second procedural reality was that postponement would have buried activation. Although the Assembly would have, technically speaking, been free to activate the Court's jurisdiction at any subsequent session, given the realities of multilateral negotiations, the outcome would very likely have been eternal postponement. After all these years, the crime of aggression would have failed to overcome a last final hurdle.' Stürchler,(n 87 ); see also ibid.

93 ibid.

94 ibid.

95 ibid 11-15.;

96 Stürchler (n 87); See also Zimmermann (n 17) 24.
} 
the adoption of the New York Activation Decision of their positions contrary to the one in OP2 would suggest that there was no agreement in substance by all of the States Parties. ${ }^{97}$

That said, the contrary positions by States Parties were expressed prior to and after the adoption of the Amendments, and not during the moment of the adoption of the Resolution by consensus. Furthermore, although decision-making by consensus it not necessarily always legally binding; ${ }^{98}$ in the present context, the New York Activation Decision is legally binding. ${ }^{99}$ Thus, adoption by consensus, is indicative of acquiescence by disagreeing States, which has the legal effect of creating an agreement between States Parties regarding the interpretation of the Rome Statute. ${ }^{100}$

It has been acknowledged that not all States Parties were present at the moment of the adoption of the New York Activation Decision. ${ }^{101}$ As such, it has been questioned whether the New York Activation Decision may be a subsequent agreement under Article 31(3)(a). ${ }^{102}$ The premise appears to question whether tacit acceptance by non-present States Parties is sufficient for the purposes of ascertaining 'objective evidence of the understanding of the parties as to the meaning of the treaty' as an authentic means of interpretation. ${ }^{103}$ Be that as it may, the will of the States Parties present at ASP was to adopt by consensus, a resolution for the interpretation of its constituent instrument. With regard to States Parties who were not present at the ASP, an argument can be made that these States had entrusted the performance of the decision to activate the ICC's jurisdiction to the plenary organ of the ICC. ${ }^{104}$ The New York Activation Decision, was thus the result of a binding decision adopted by the Plenary Organ of the ICC, which 'may have contractual effects at the level of treaty interpretation. ${ }^{105}$ The present inquiry turns to Draft Conclusion 12, paragraph 2, which stipulates that subsequent agreements [...] under article 31(3) [...] 'may arise from, or be expressed in, the practice of an international organization in the application of its constituent instrument.' Thus, it is submitted that the New York Activation Decision is a subsequent agreement under Article 31(3)(a), which may be a means of interpretation for the Rome Statute.

\footnotetext{
97 Akande and Tzanakopoulos (n 12) 946.

98 Schermers and Blokker (n 4) 561.

99 OP1: Decides to activate[...].

100 The ICJ has observed that in relation to non-binding resolutions, adoption by consensus nonetheless carries weight, Whaling in the Antarctic (Australia v Japan, New Zealand Intervening), Judgment 31 March 2014, ICJ Reports (2014), 226, at para.46 ('However, when they are adopted by consensus or by a unanimous vote, they may be relevant for the interpretation of the Convention or its Schedule.')

${ }^{101}$ Stürchler (n 87 ); Akande and Tzanakopoulos (n 12) 946.; Zimmermann contemplates the position of non-present States Parties, at Zimmermann (n 17) 25.

102 Akande and Tzanakopoulos (n 12) 946. See also Jon Kevin Heller, 'The Uncertain Legal Status of the Aggression Understandings" (2012) 10 Journal of International Criminal Justice 229, 237-239.

103 draft Conclusion 3, ILC Conclusions.

104 Richard Gardiner, Treaty Interpretation (2nd edn, Oxford University Press 2015) 281.

105 Ahlborn (n 74) 427.
} 
According to the law of treaties, the starting point is Article 31(1), which will interpret Articles 12,15 bis(4) and 121(5) of the Rome Statute in 'good faith in accordance with the ordinary meaning to be given' in their 'context', which shall comprise Resolution RC/Res.6, and 'to be taken into account, together with the context', the New York Activation Decision which amounts to a subsequent agreement under Article 31(3). Thus, OP2 may contribute to clarifying the meaning of Article 15 bis(4), ${ }^{106}$ which may result in 'narrowing' the interpretation of the jurisdictional regime of the ICC over this crime. ${ }^{107}$ This would mean that the Kampala Amendments enter into force in accordance with the Rome Statute - and not the tacitly amended amendment regime adopted in Kampala. Accordingly, the ICC may exercise jurisdiction over the crime of aggression in the event of State referrals and proprio motu investigations only if both the intended aggressed State and the alleged aggressor State have ratified the amendments.

However, there is also the possibility that the New York Activation Decision, even as a subsequent agreement under Article 31(3)(a) may not serve any clarification as the ILC has also commented that 'the interpreter must give appropriate weight to such an interpretive resolution under article 31 (paragraph 3(a) and (b), but not necessarily treat it as legally binding. ${ }^{, 108}$ Thus, it is for the interpreter to decide that the New York Activation Decision is a subsequent agreement under Article 31(3)(a), and the appropriate weight to this interpretive instrument accordingly.

In the event that the interpreter is not satisfied that the New York Activation Decision is a subsequent agreement under Article 31(3)(a), it may nevertheless be considered as subsequent practice according to Article 32 of VCLT. ${ }^{109}$ The recent ILC Conclusions has stipulated in Conclusion 4, para.3 that:

A subsequent practice as a supplementary means of interpretation under article 32 consists of conduct by one or more parties in the application of the treaty, after its conclusion. ${ }^{110}$

This is perhaps most likely if the interpreter is not satisfied, possibly in reliance on the framework of the ILC Conclusions, that the New York Activation Decision did not constitute an

\footnotetext{
106 draft Conclusion 7, paragraph 1, ILC Conclusions.

${ }^{107}$ Commentary to draft Conclusion 7, paragraph 1, Commentary to ILC Conclusions, p.52, para.7.

108 Commentary to draft Conclusion 11, p.93, para.37.

${ }^{109}$ Draft Conclusion 2, paragraph 1, ILC Conclusions ('Articles 31 and 32 of the Vienna Convention on the Law of Treaties set forth, respectively, the general rule of interpretation and the recourse to supplementary means of interpretation. These rules also apply as customary international law.')

${ }^{110}$ In the Commentary to Draft Conclusion 4, paragraph 3, it is stated 'any practice in the application of the treaty that may provide indications as to how the treaty is to be interpreted may be a relevant supplementary means of interpretation under article 32,' Conclusions on subsequent agreements and subsequent practice in relation to the interpretation of treaties, with commentaries 2018, A/73/10 (hereinafter "Commentary to ILC Conclusions"), p.33,para.24.
} 
agreement between States Parties on the interpretation as stipulated in OP2. According to the ILC, under Article 32, “this form of subsequent practice, [...] does not require the agreement of all parties. ${ }^{, 111}$ Although subsequent practice under article 32 does not establish the agreement of the parties unlike subsequent practice under article 31, it nevertheless also contributes to the clarification of the meaning of a treaty. ${ }^{112}$ Furthermore, Article 31 as the general rule of interpretation, and article 32 as recourse to supplementary means of interpretation, must be read together as they are rules of customary international law, ${ }^{113}$ and 'constitute an integrated framework for the interpretation of treaties. ${ }^{114}$

Accordingly, if the New York Activation Decision is a subsequent practice under Article 32(2) VCLT, OP2 may be used to confirm the meaning of the Rome Statute in accordance with Article $31{ }^{115}$ Yet, the ICC has the discretion whether to take into account supplementary means of interpretation as Article 32 stipulates 'recourse may be had', in contrast to 'shall' under Article 31 with regard to the general rule of interpretation. Furthermore, supplementary means of interpretation under Article 32 comprises 'preparatory work of the treaty' in addition to 'circumstances of its conclusion'. Thus, in accordance with Article 32, the Court would thus have recourse to consider preparatory works from Rome to Kampala to New York, as well as the New York Activation Decision as subsequent practice, to confirm the meaning of Articles 15 bis(4) and Article 121 of the Rome Statute pursuant to Article 31 of the VCLT. In this light, the negotiation history from Rome to Kampala is more consistent with the position of States Parties that espouse the jurisdictional regime of the ICC is premised on tacit consent/opt-out, i.e. the broader position. That said, the New York Activation Decision, had 'arisen' from or was 'expressed' in the practice of the ASP as an organ of the ICC in the application of its constituent instrument. ${ }^{116}$ Thus, the text of OP2 may be particularly instructive in confirming the narrow position on jurisdiction: i.e., the ICC can only exercise jurisdiction over the crime of aggression if both the intended aggressed State and alleged aggressor State have ratified.

Ultimately, it is for the interpreter to decide whether the New York Activation Decision is a subsequent agreement under Article 31(3)(a) of the VCLT or subsequent practice under Article 32. Also, as mentioned above, the characterization of the New York Activation Decision as a

\footnotetext{
111 Commentary to draft Conclusion 4, paragraph 3, at p.33, para.23; see also Commentary to draft conclusion 4, paragraph 2, at 31, para.16.

112 Draft Conclusion 7, paragraph 3, ILC Conclusions.

113 Draft Conclusion 2, paragraph 1, ILC Conclusions; for practice of courts and tribunals that have acknowledged the customary character of these rules, see Commentary to draft Conclusion 2, paragraph 1, at p.18-19, para.4.

114 Commentary to draft Conclusion 2, paragraph 1, at p.17, para.3.

115 Akande and Tzanakopoulos (n 12) 948-949.

116 Draft Conclusion 12, paragraph 2.
} 
subsequent agreement under Article 31(3)(a) would not necessarily be legally binding, ${ }^{117}$ or 'necessarily conclusive in the sense that it overrides all other means of interpretation., 118

\subsection{The New York Activation Decision as a rule of the organization}

The Rome Statute is a constituent instrument of an international organization, to which the VCLT and law of treaties applies. ${ }^{119}$ Constituent instruments are multilateral treaties that are special in nature. ${ }^{120}$ The ICJ said in the Legality of the Use by a State of Nuclear Weapons in Armed Conflict Advisory opinion:

But the constituent instruments of international organizations are also treaties of a particular type; their object is to create new subjects of law endowed with a certain autonomy, to which the parties entrust the task of realizing common goals. Such treaties can raise specific problems of interpretation owing, inter alia, to their character which is conventional and at the same time institutional; the very nature of the organization created, the objectives which have been assigned to it by its founders, the imperatives associated with the effective performance of its functions, as well as its own practice, are all elements which may deserve special attention when the time comes to interpret these constituent treaties. $^{121}$

Draft Conclusion 12 of the ILC Conclusions confirms that rules on treaty interpretation are applicable to the constituent instruments of international organizations. In particular, it provides guidance with regard to the way in which subsequent agreements shall be taken into account in the interpretation of the constituent treaty in accordance with Articles 31 and 32. Paragraph 1, affirms that subsequent agreements under Article 31(3) and subsequent practice under Article 32 may be a means of interpretation for the constituent instrument in accordance with Articles 31 and 32. As discussed above, pursuant to Draft Conclusion, paragraph 2, the New York Activation Decision may be considered as a subsequent agreement that may arise from, or be expressed, in the practice of the plenary organ of the ICC in the application of its constituent instrument.

\footnotetext{
117 Commentary to draft conclusion 3, p.24-25, para.4.

118 Commentary to draft conclusion 3, p.25, para.4.

${ }^{119}$ Legality of the Use by a State of Nuclear Weapons in Armed Conflict, Advisory Opinion, I.C.J. Reports 1996, p.66, para.19.

${ }^{120}$ Certain Expenses of the United Nations (Article 17, paragraph 2, of the Charter), Advisory Opinion, I.C.J.Reports 1962, p.151, 157; Schermers and Blokker (n 4) 759.

121 I. C. J. Reports 1996, p. 66, para.19. see also Ahlborn (n 74) 425.
} 
The problem with the argument that the New York Activation Decision may be considered as a subsequent agreement or practice under Article 31 of the Vienna Convention is that not all States Parties were present at the ASP. In this regard, it is significant that the Rome Statute is the constituent instrument of the ICC. It has a dual nature as a contract and a constitution, which gives rise to new rules that might not have been foreseen in the original founding treaty and were not brought about by a formal treaty amendment procedure. ${ }^{122}$ It is for this reason that the ICJ referred to the constituent instruments of international organizations as "treaties of a particular type'.

Indeed, while Conclusion 12 of the ILC Conclusions affirms the applicability of Article 31 of the Vienna Convention to the constituent instruments of international organizations, it also includes an important caveat. As stated, in paragraph 4: "Paragraphs 1 to 3 apply to the interpretation of any treaty which is the constituent instrument of an international organization without prejudice to any relevant rules of the organization. This wording reflects Article 5 VCLT, which stipulates that the rules in the VCLT are 'without prejudice to any relevant rules of the organization. ${ }^{123}$ The 'rules of the organization' were defined in the Article 2(b) of the ILC Draft Articles on the responsibility of international organization 2011: This reflects Article 5 VCLT, which stipulates that the rules in the VCLT are 'without prejudice to any relevant rules of the organization. ${ }^{124}$ The 'rules of the organization' were defined in the Article 2(b) of the ILC Draft Articles on the responsibility of international organization 2011: "rules of the organization" means, in particular, the constituent instruments, decisions, resolutions and other acts of the international organization adopted in accordance with those instruments, and established practice of the organization."

While the characterization of the New York Activation Decision as a subsequent agreement or subsequent practice amongst the parties to the Rome Statute may be questions, the decision is clearly a rule of the organization, taken by one of its organs: the ASP. As is well known, international organizations may have different modes of decision-making and for the entry into force of those decisions. ${ }^{125}$ It may not be required that all member states participate in the decisionmaking, or vote in favor of a particular decision, for it to become effective. This stands in notable contrast to the entry into force of a treaty, which requires the explicit consent to be bound by the

\footnotetext{
122 ibid 403; Schermers and Blokker (n 4) 876.

123 Gardiner (n 105) 281.

124 ibid.

125 Schermers and Blokker (n 4) 783-784.
} 
treaty. ${ }^{126}$ In the same vein, the "established practice" of an organization, as part of the rules of the organization can be distinguished from subsequent practice under the Vienna Convention. ${ }^{127}$

The question is whether the New York Activation Decision itself may constitute a "relevant rule" of interpretation with regard to the Rome Statute. As such, the New York Activation Decision may take precedence over the general rules of interpretation in Article 31 and 32 VCLT, ${ }^{128}$ particularly when the interpreter is an organ of the International Organization, i.e. the Appeals Division; Trial Division and Pre-Trial Division. ${ }^{129}$ It is likely that the organ of the ICC that interprets the Rome Statute on the crime of aggression would rely on the OP2 of the New York Activation Decision as a clause or "relevant rule" regarding the jurisdictional regime of the ICC in the event of State referrals and proprio motu investigations. By comparison, an interpreter who is not an organ of the ICC, e.g. the ICJ, would rely on the law of treaties and not the rules of the organization. Accordingly, as the Rome Statute and the Kampala Amendments are not easily reconcilable, the New York Activation Decision will likely be referred to as a subsequent agreement under Article 31(3)(a) to confirm the meaning of the relevant terms of the Rome Statute in accordance with the general rule of interpretation in Article 31.

Even if the New York Activation Decision is characterized as a "rule of the organization", it must be emphasized that the decision itself reaffirms the regular amendment procedure under the Rome Statute, which requires the ratification of the Kampala Amendments by a state for the ICC to have jurisdiction over that state in relation to the crime of aggression. In that sense, the New York Activation decision reconciles the inconsistences between former Article 5 (2) of the Rome Statute and Article 15 bis (4) of the Kampala Amendments under both the law of treaties and international institutional law.

\section{Settlement of disputes}

The starting point for reflecting upon settlement of disputes is that the Rome Statute is an international treaty, and therefore general rules on settlement of international disputes are applicable to it. The earlier analysis has identified discreet issues of interpretation of the Rome Statute that, if unresolved, constitute disputes between its States Parties with regard to the jurisdictional regime of the ICC over the crime of aggression both in the case of State referrals and

\footnotetext{
126 Article 24, VCLT.

127 Ahlborn submits that ' $[\mathrm{w}]$ hile the principle of subsequent practice in the law of treaties is based on the premise that all parties to the treaty participate in its reinterpretation, institutional practice may often include only a fraction of the actual membership or original founders of the organization.' Ahlborn ( $\mathrm{n} 74) 427$.

128 Commentary to Draft Conclusion 12, paragraph 4, at p.104, para.39.

129 Article 34, Rome Statute.
} 
proprio motu investigations by the ICC Prosecutor. It is a trite point that disputes relating to the Rome Statute, including disputes relating to its interpretation, have to be settled in accordance with international law, just as any other disputes regarding international treaties. A slight wrinkle to the application of general principles of international dispute settlement is provided by the perhaps slightly unusual interplay between the general rules and the mechanisms provided for in the instrument itself.

International legal order is highly flexible regarding the choice of dispute settlement means and mechanisms, and particularly deferential to choices of parties. An authoritative expression of this general systemic preference, articulated with an eye to international peace and security and therefore particularly relevant for the topic under discussion, is Article 33(1) of the UN Charter, which provides that:

The parties to any dispute, the continuance of which is likely to endanger the maintenance of international peace and security, shall, first of all, seek a solution by negotiation, enquiry, mediation, conciliation, arbitration, judicial settlement, resort to regional agencies or arrangements, or other peaceful means of their own choice.

States Parties thus have a variety of means for the peaceful settlement of their disputes pertaining to the Rome Statute on the crime of aggression as Article 33(1) is not exhaustive and explicitly provides States with the option of 'other peaceful means of their own choice'. The implication of the language of 'choice' used by the UN Charter is that all formalized dispute settlement mechanisms require an opt-in in the form of consent to be operational: in the words of the PCIJ that still reflect positive law on the issue, 'no State can, without its consent, be compelled to submit its disputes with other States either to mediation or to arbitration, or to any other kind of pacific settlement. ${ }^{130}$ Consequently, the available mechanisms of dispute settlement will be provided by a combination of mechanisms to which States are generally subject and that cover disputes about the Rome Statute, and the special regime provided by the Rome Statute for dispute settlement between States Parties. The somewhat atypical Article 119 of the Rome Statute is worth quoting in full:

1. Any dispute concerning the judicial functions of the Court shall be settled by the decision of the Court.

\footnotetext{
130 Status of the Eastern Carelia (Advisory Opinion), PCIJ Ser B, 1923, No.5, p.27, and more recently Immunities and Criminal Proceedings (Equatorial Guinea v France) (Preliminary Objections) [2018] ICJ Rep para. 42.
} 
2. Any other dispute between two or more States Parties relating to the interpretation or application of this Statute which is not settled through negotiations within three months of their commencement shall be referred to the Assembly of States Parties. The Assembly may itself seek to settle the dispute or may make recommendations on further means of settlement of the dispute, including referral to the International Court of Justice in conformity with the Statute of that Court.

Two separate mechanisms for dispute settlement exist within the framework of the Rome Statute, each expressed in a separate paragraph, ${ }^{131}$ The scope of both paragraphs is set by the concept of 'a dispute', which is not given a special meaning and can therefore be taken to refer to its ordinary meaning in international law of dispute settlement. The most recent contemporary elaboration of the concept was provided by the International Court of Justice in the trio of cases regarding Obligations concerning Negotiations Relating to Cessation of the Nuclear Arms Race and to Nuclear Disarmament, where the ICJ both confirmed the classic definition of a dispute, ${ }^{132}$ and applied in a rather stringent manner, calling for a clear opposition of views between particular parties regarding legal issues (and general statements in a multilateral context would not suffice). ${ }^{133}$ The distinction between disputes subject to the first and the second paragraph are drawn by reference to 'the judicial function of the Court': a dispute pertaining to this class of affairs falls under the first paragraph, while '[a]ny other dispute ... relating to the interpretation or application' of the Rome Statute falls under the second paragraph. Interpretation of the scope of 'judicial function' is therefore a key element in determining the operation of dispute settlement mechanisms.

The Rome Statute does not provide a special meaning or a technical definition for the cjudicial function', nor do the Rules of Procedure. ${ }^{134}$ The terms are also used in the Rome Statute in relation to the role of Chambers, ${ }^{135}$ and independence of judges ${ }^{136}$ but not in a manner that can provide helpful context for interpreting Article 119(1). It therefore seems that the ordinary meaning of 'judicial function' in international law of international courts and tribunals must be applied here. Accordingly, 'judicial function' does not appear to have a set technical meaning but rather reflects

\footnotetext{
${ }^{131}$ Alain Pellet, 'Settlement of Disputes', The Rome Statute of the International Criminal Court: A Commentary, vol II (Oxford University Press 2002) 1842-1844.

132 Case concerning East Timor - para.99; Case of Mavrommatis Palestine Concessions, P.C.I.J., Ser.A, No.2.,1,11(1924).

133 Obligations concerning Negotiations relating to Cessation of the Nuclear Arms Race and to Nuclear Disarmament (Marshal Islands v UK) (Preliminary Objections) [2016] ICJ Rep 833 paras. 26-58.

134 Schabas (n 21) 1484.

135 Article 39(2)(a), Rome Statute.

136 Article 40(2), Rome Statute.
} 
the structural and functional peculiarities of particular institutions, and indeed its very scope and purpose may be subject to disagreement. For example, the International Court of Justice has in its recent practice noted that its judicial function is protected by the principle of res judicata, ${ }^{137}$ in contentious cases is to decide disputes, ${ }^{138}$ that an element of its judicial function is that its judgments have practical consequences, and that its exercise is not precluded by negotiations, ${ }^{139}$ and its President noted separately that the judicial function is satisfied by rejecting the relief requested not sufficiently founded in law. ${ }^{140}$ And, of course, judicial function in international law is a subject of rich and diverse scholarly discussion. ${ }^{141}$ Taking all of those points together, it seems that 'judicial function' may be read as including those decisions necessarily taken in the normal exercise of judicial activities, and would at a minimum include decisions on jurisdiction, admissibility, and applicable law, definition of crimes and their application to factual circumstances, and decisions on co-operation with the Court. ${ }^{142}$ The 'settled' aspect of the provision refers to Article 150(2) of the Statute, according to which the final decision of the Appeals Chamber is final and binding on the parties.

It is worth noting a somewhat curious aspect of OP3 of the New York Activation Decision, namely that it reaffirmed Article 119(1) in light of judicial independence of the judges of the Court, even though it relates to judicial function, which may entail impartiality of judges but, as suggested above, is certainly broader in scope. Be that as it may, a dispute pertaining to the judicial function of the Court is most likely to entail questions of jurisdiction over the crime of aggression. If an alleged aggressor State Party disagrees with the Court's exercise of jurisdiction over a crime of aggression, this would be a challenge to the jurisdiction of the Court under Article 19 (Article 19(2)(c) may be particularly relevant as it allows a State from which acceptance of jurisdiction is required under article 12 to challenge the jurisdiction of the Court). It would also be, if the reading of 'judicial function' suggested above is accepted, a challenge falling under Article 191(1) and therefore capable of being pursued to the extent that the Rome Statute's procedure permits,

\footnotetext{
137 Question of the Delimitation of the Continental Shelf between Nicaragua and Colombia beyond 200 Nautical Miles from the Nicaraguan Coast (Nicaragua v Colombia) [2016] ICJ Rep 100, para. 58.

138 Frontier Dispute (Burkina Faso/Niger) [2013] ICJ Rep 44, paras. 45-48, 53.

139 Application of the Interim Accord of 13 September 1995 (FRYOM v Greece) [2011] ICJ Rep 644, paras. $47,57$.

140 Obligation to Negotiate Access to the Pacific Ocean (Bolivia v Chile) [2018] ICJ Rep, Declaration of President Yusuf, para 8.

141 See the variety of perspectives David D Caron, 'David Caron, "International Courts and Tribunals: Their Role Amidst a World of Courts” (2011) 26 ICSID Review' (2011) 26 ICSID Review 1; Vaughan Lowe, 'The Function of Litigation in International Society’ (2012) 61 International \& Comparative Law Quarterly 209; Armin Von Bogdandy and Ingo Venzke, 'On the Functions of International Courts: An Appraisal in Light of Their Burgeoning Public Authority' (2013) 26 Leiden Journal of International Law 49; Gleider Hernandez, The International Court of Justice and the Judicial Function (Oxford University Press 2014).

${ }^{142}$ For a further list of suggestions for what may constitute a 'judicial function', see Roger Clark, 'Article 119: Settlement of Disputes' in Otto Triffterer and Kai Ambos (eds), Rome Statute of the International Criminal Court: A Commentary (3rd edn, CHBeck Hart Nomos 2016) 2276-2277.
} 
namely to the Appeals Chamber. Does the language of 'settled' affect rights that States would otherwise have to access dispute settlement mechanisms agreed upon elsewhere, e.g. under the Optional Clause of the ICJ? Judicial authority has somewhat differed in its emphasis on interaction of various international tribunals where the other tribunal is not explicitly excluded, ${ }^{143}$ but in this instance it is plausible to treat 'settled' as language excluding other mechanisms, if not explicitly then by necessary implication. It may be helpful to distinguish the effect of Article 191(1) on the State Party that resorts to another mechanism - a breach of its obligations seems likely - and its effects on that mechanism. In practice, the effect of Article 191(1) will turn on the willingness of the other court or tribunal to desist from proceeding due to the State's (or States') consent to Article 191(1), and much will turn on that tribunal perception of $i t s$ judicial function and whether it permits waivers or qualifications of judicial access in such a manner. An even harder question is whether, in the event of a Security Council referral, where the ICC exercises jurisdiction over the national of a non-State Party for an act of aggression it has allegedly committed, the effect of Article 119(1) is to preclude the non-State Party from raising a dispute in relation to the judicial function of the ICC in this regard in a different forum of its choice; e.g., if the non-State Party concerned is involved with another State in a contentious case before the ICJ where the judicial function of the ICC will be considered. Much would depend on the language that the Security Council uses in the referral, and the extent to which this provision of the Rome Statute is treated as directly applicable or substantively replicated by the relevant resolution.

As noted above, there may be reasonable disagreement over whether 'judicial function' covers all aspects of disputes about aggression. If the particular dispute does not fall under Article 119(1), it will be covered by Article 119(2). The dispute between States Parties with regard to the interpretation of the Rome Statute on the crime of aggression may exist separately, as well as in parallel, with a dispute over the judicial function of the Court. Thus, irrespective of the initiation or commencement of any proceedings on the crime of aggression at the ICC, a disagreement between one or two more States Parties with regard to the scope of the Court's jurisdiction over the crime may wish to settle their disputes in accordance with Article 119(2), provided that the dispute between States Parties falls within the meaning of 'interpretation or application' of the Rome Statute. $^{144}$

\footnotetext{
143 Philippines v China, PCA Case no 2013-19, Award on Jurisdiction and Admissibility, 29 October 2015, paras.222229.

${ }^{144}$ In the Oil Platforms Case, in relation to whether a dispute existed between the Parties 'as to the interpretation or application' of a treaty, the ICJ held that it could not 'limit itself to noting that one of the Parties maintains that such a dispute exists, and the other denies it', Oil Platforms (Islamic Republic of Iran v. United States of America), Preliminary Objection, Judgment, I.C.J. Reports 1996, p. 803, para.16.; For a list of suggestions of disagreements that may fall within this category, see Clark, 'Article 119: Settle of Disputes' (n 143) 2278.
} 
Article 119(2) provides for two mechanisms. The first mechanism comprises bilateral or multilateral negotiations between States Parties. ${ }^{145}$ The ICJ held in the North Sea Continental Shelf cases that parties concerned are 'under an obligation so to conduct themselves that the negotiations are meaningful, which will not be the case when either of them insists upon its own position without contemplating any modification to it. ${ }^{146}$ It is unclear whether the concerned Parties or the ASP are to decide whether the 'dispute cannot be settled by diplomatic negotiation, ${ }^{147}$ and thus refer the dispute to the ASP. Be that as it may, the ASP as the second mechanism for dispute settlement, will have to satisfy itself that negotiations had taken place for three months, ${ }^{148}$ and were unsuccessful; ${ }^{149}$ upon which, it may either seek to settle the dispute itself, or make recommendations on further means of settlement, which also includes a referral to the ICJ.

For the ASP to settle the dispute itself, Article 121(2)(g) of the Rome Statute provides the ASP with the power to perform any function consistent with this Statute, which in present context is to settle the dispute between States Parties. The ASP also has the power to create subsidiary bodies (organs) as may be necessary. ${ }^{150}$ It is not clear whether decisions by the ASP or intended subsidiary organs pertaining to the dispute will be legally binding on States Parties, and there is something to be said for taking the nemo dat quod non babet position on the ability of institutions to create agents that have more powers than their principals. ${ }^{151}$ In any event, 'recommendations on further means of settlement' made by the ASP will not be binding on States Parties, as they have the freedom of choice with regard to the means of dispute settlement and may choose to not comply with the recommendations. ${ }^{152}$ Furthermore, as States Parties must consent to any form of dispute settlement, they are under no obligation to settle their disputes. Thus, Article 119(2) does not preclude the general regime pursuant to Article 33(1) of the UN Charter. ${ }^{153}$

It is also not clear whether recommendations by the ASP encompassing a referral to the ICJ relates to a contentious proceeding or an advisory proceeding. The former may make more sense than the latter in the context of settling a dispute between two (or more) States Parties; yet, with regard to contentious proceedings, contesting States Parties are under no obligation to follow this

\footnotetext{
145 Manila Declaration on the Peaceful Settlement of Disputes, UN Doc.S/Res/37/10, para.9.

146 North Sea Continental Shelf Judgment, I.C.J. Reports 1969, p. 3 , para.85

147 Mavromattis Case, PCIJ, Series A, No.2, 1924, p.13.

148 Clark, 'Article 119: Settle of Disputes' (n 143) 2279.

149 Pellet, 'Settlement of Disputes' (n 132) 1845.

150 Article 112(4), Rome Statute.; see also Clark, 'Article 119: Settle of Disputes' (n 143) 2279; Pellet, 'Settlement of Disputes' (n 132) 1845.

${ }^{151}$ For an affirmative view that the ASP may adopt a binding settlement procedure, see Schabas (n 21) 1486.

152 Pellet, 'Settlement of Disputes' (n 132) 1847.

153 Clark, 'Article 119: Settle of Disputes' (n 143) 2279; Pellet, 'Settlement of Disputes' (n 132) 1846.
} 
recommendation. ${ }^{154}$ Pellet suggests that the ICJ may only exercise jurisdiction in light of such a recommendation by the ASP if : '(1) the parties to the dispute sign a special agreement referring it to the International Court; or (2) if pre-existing bilateral or multilateral treaty includes a provision constituting a basis for the jurisdiction of the Court in conformity with Article 36(1) of its Statute; or (3) if the States Parties have both made an optional declaration under Article 36(2) without any relevant reservation. ${ }^{155}$ Under Article 96(a) of the UN Charter, 'the General Assembly of the Security Council may request the ICJ to give an advisory opinion on any legal question'; while 96(b) stipulates that the General Assembly may authorize other organs of the UN and specialized agencies, 'to request advisory opinions of the Court on legal questions arising within the scope of their activities. ${ }^{, 156}$ As the ICC is neither an organ of the UN or a specialized agency, ${ }^{157}$ it is questionable whether the General Assembly may authorize the Court to request an advisory opinion of the ICJ. ${ }^{158}$ Much would depend on the way how the request is drafted, and the African Union's possible request of an advisory opinion regarding immunities of heads of State is likely to provide practical guidance: it is plausible to expect that both constitutionally and politically the GA would be more inclined to request an opinion on a general legal issue rather than invite the ICJ to act as a de facto review authority. ${ }^{159}$ Indeed, the more that resort to the ICJ or another international tribunal approaches review of ICC's decisions, the stronger the argument that the 'judicial function' criterion in Article 119(1) is triggered, and the decision in question must be treated as 'settled'.

\footnotetext{
${ }^{154}$ Clark, 'Article 119: Settle of Disputes' (n 143) 2280.; cf. Article 9, Convention on the Prevention and Punishment of the Crime of Genocide; see also Schabas (n 21) 1486.

155 Pellet, 'Settlement of Disputes' (n 132) 1847.

156 The negotiation history shows that Mexico and Spain, contemplated that the GA would empower the ASP to request advisory opinions from the ICJ, see Clark, 'Article 119: Settle of Disputes' (n 143) 2280.;

${ }^{157}$ Note that the GA authorized the International Atomic Energy Agency to request advisory opinions of the ICJ in GA Resolution 1146 (XII); Article 14 (5) of the Chemical Weapons Convention 1993 stipulates: 'The Conference and the Executive Council are separately empowered, subject to authorization from the General Assembly of the United Nations, to request the International Court of Justice to give an advisory opinion on any legal question arising within the scope of the activities of the Organization. An agreement between the Organization and the United Nations shall be concluded for this purpose in accordance with Article VIII, paragraph 34 (a).', for a criticism see Pellet, 'Settlement of Disputes' (n 132) 1848.

158 see ibid.; But see Schabas (n 21) 1488.('Although the Assembly of States Parties cannot on its own invoke the advisory opinion jurisdiction of the International Court of Justice, its membership is sufficiently influential within the General Assembly to ensure the success of a resolution in accordance with article 96 of the UN Charter').

${ }^{159}$ Letter dated 9 July 2018 from the Permanent Representative of Kenya to the UN addressed to the SG, 'Request for an advisory opinion of the International Court of Justice on the consequences of legal obligations of States under different sources of international law with respect to immunities of Heads of State and Government and other senior officials' (18 July 2018) UN Doc A/73/144.
} 


\section{Concluding Remarks}

The enquiry above has shown that States Parties in Kampala had tacitly amended the Rome Statute with regard to Article 121, the article governing amendments. Thus, pursuant to Resolution RC/Res.6, the Kampala Amendments enter into force in accordance with the first sentence of Article 121(5) of the Rome Statute so as to give legal effect to Article 15 bis(4) with regard to the jurisdiction of the ICC over the crime of aggression in the event of State referrals and proprio motu investigations. This had led to ambiguity with respect to whether the amendments on the crime of aggression, including the provisions stipulating the exercise of jurisdiction, should enter into force in accordance with the Rome Statute or the Kampala Amendments. The answer is that the tacit amendment by States Parties gives effect to the latter. Thus, the ICC may exercise jurisdiction over the crime of aggression as long as either the intended aggressed State or the alleged aggressor State have ratified the Kampala Amendments. The jurisdictional scope of the ICC in the event of State referrals and proprio motu investigations is thus premised on a tacit consent/opt-out one.

However, the New York Activation Decision appears to hold that Article 121(5) should be read in accordance with the Rome Statute and not the Kampala Amendments. The interpreter is likely to view the New York Activation Decision as a subsequent agreement under Article 31(3)(a) of the VCLT as an authentic means of interpretation of the Rome Statute in accordance with Article 31(1). In the event that the interpreter is an organ of the ICC, the New York Activation Decision is a Rule of the International Organization. Thus, the New York Activation Decision espouses the narrower position of jurisdiction. The legal and practical effect is that the ICC may only exercise jurisdiction over a national for the crime of aggression if both the intended aggressed State Party and aggressor State Party have ratified the amendments.

Ultimately, the ICC has the Kompetenz-Kompetenz to satisfy itself of the jurisdiction over the crime of aggression, including the scope of this jurisdiction. The Court also has the KompetenzKompetenz to settle disputes with regard to its judicial function, which may include its interpretation of the Rome Statute on the crime of aggression. With regard to disputes that States may have other than 'judicial function' of the ICC, the ASP may be a mechanism for settlement - but does not necessarily preclude other mechanisms of dispute settlement under international law.

This article has brought to light the interplay between international institutional law, the law of treaties and dispute settlement in the contemplation of the activation of the ICC's jurisdiction over the crime of aggression. In particular, the questions of amendment and interpretation of the Rome Statute, demonstrate the sophistication of constituent instruments of International Organization and the freedom afforded to member States to make decisions in Conferences of 
States Parties. Indeed, it would appear that States have rather extensive freedom under international law in this regard. The consideration of dispute settlement mechanisms, both the specialist regime in the Rome Statute and the more generalist regime in the international legal order, also demonstrates how international legal order also provides freedom to States with regard to their choices of dispute settlement means and mechanisms. 